Volume. 2 Nomor. 2

Periode: Juli - Desember 2018; hal. 1-9

p-ISSN : 2580-1112; e-ISSN : 2655-6669

Copyrighr@2018

Penulis memiliki hak cipta atas artikel ini

Jurnal Ilmiah Keperawatan Orthopedi

(JIKO)

journal homepage:

https://ejournal.akperfatmawati.ac.id

\title{
Upaya Meningkatkan Berat Badan Bblr Melalui Intervensi Comfort Food For The Soul Kolcaba (Perawatan Metode Kanguru)
}

\author{
Ayuda Nia Agustina ${ }^{1}$, Yeni Rustina ${ }^{2}$, Fajar Triwaluyanti ${ }^{3}$ \\ Akademi Keperawatan Fatmawati, Jakarta
}

\begin{abstract}
Abstrak
Nutrisi yang adekuat diperlukan untuk proses penyembuhan, pertumbuhan dan perkembangan bayi berat lahir rendah, namun belum semua perawat mampu memfasilitasi pemenuhan kebutuhan nutrisi yang adekuat. Penelitian ini menganalisis penerapan model kenyamanan Kolcaba dalam memenuhi kebutuhan nutrisi pada bayi berat lahir rendah. Desain yang digunakan adalah studi kasus, terdapat lima kasus yang dibahas. Diagnosis keperawatan yang dirumuskan adalah: Ketidakefektifan pola menyusu pada bayi, ketidakseimbangan nutrisi: kurang dari kebutuhan tubuh, ketidakcukupan ASI, kekurangan volume cairan, risiko infeksi, ketidakefektifan termoregulasi: Hipotermia, pola nafas tidak efektif. Intervensi utama yang diterapkan adalah perawatan metode kanguru dan terapi musik. Hasil akhir penerapan model kenyamanan Kolcaba menunjukkan bahwa perawatan metode kanguru dan terapi musik dapat memfasilitasi pemenuhan kebutuhan nutrisi pada bayi berat lahir rendah ditunjukkan dengan adanya peningkatan berat badan per hari dan meningkatnya produksi ASI. Asuhan berpusat pada keluarga seperti perawatan metode kanguru penting untuk memfasilitasi kenyamanan dan pemenuhan kebutuhan nutrisi pada bayi berat lahir rendah.
\end{abstract}

Kata Kunci: Bayi Berat Lahir Rendah, Pemenuhan Kebutuhan Nutrisi, Model Kenyamanan Kolcaba, Perawatan Metode Kanguru.

\begin{abstract}
Adequate nutrition needed for healing, growth and development of low birth weight infants, but not all nurses are able to facilitate the fulfillment of adequate nutrition. This paper analyzes the application of a Kolcaba's comfort model to facilitate nutritional needs of low birth weight infants. The design used is a case study, there were five cases discussed. Nursing diagnosis were taken are: ineffectives infant feeding pattern, unbalanced nutrition: less than body requirements, insufficient breastfeeding, deficient fluid volume, risk of infection, ineffective thermoregulation: hypothermia, ineffective breathing pattern. The primary intervention treatment method used is kangaroo mother care and music therapy. The final result of the application Kolcaba's comfort model indicates that kangaroo mother care and music therapy can facilitate fulfilling the nutritional needs of low birth weight infants indicated by an increase of body weight per day and increased milk production. Family-centered care method such as kangaroo
\end{abstract}

1,2,3 e-mail: ayudania.agustina@gmail.com 
mother care is essential to facilitate comfort and fulfillment of the nutritional needs of low birth weight infants.

Keywords: Low Birth Weight Infant, Fullfillment of Nutritional Needs, Kolcaba's Comfort Model, Kangaroo Mother Care.

\section{Pendahuluan}

Bayi Berat Lahir Rendah (BBLR) ialah bayi baru lahir yang berat badannya saat lahir kurang dari 2500 gram tanpa memandang usia gestasi. BBLR tidak hanya terjadi pada bayi cukup bulan yang mengalami hambatan pertumbuhan selama kehamilan (IUGR) namun juga dapat terjadi pada bayi kondisi prematur (Aritonanga, Rajagukguk \& Nasution, 2015).

\section{Fungsi sistem tubuh yang belum} optimal menyebabkan BBLR memerlukan perawatan yang lebih intensif. BBLR memiliki kebututuhan yang meliputi aspek fisiologis, psikologis dan sosial. Kebutuhan fisiologis diantaranya suhu tubuh yang hangat, daya tahan tubuh yang baik, memperoleh ASI dan banyak kebutuhan lainnya. Kebutuhan psikologis berupa kasih sayang, perhatian, dan kedekatan dengan orang tua, terutama ibu (Benzies, Magill-Evans, Hayden \& Ballantyne, 2013).

Bayi dengan kondisi berat lahir rendah, umumnya akan mengalami hospitalisasi. Dampak dari ketidaknyamanan selama hospitalisasi antara lain: Terganggunya proses pembentukan rasa percaya, penurunan sense of control dan nyeri, stres akibat stimulus yang berlebihan pada cahaya, lingkungan dan suara (Altimier, 2011), suhu tubuh tidak stabil dan pertambahan berat badan lambat serta mempengaruhi perkembangan saraf bayi (Altimier \& Phillips, 2013).

Hospitalisasi juga menyebabkan perpisahan antara orang tua dengan bayi, sehingga para orang tua khususnya ibu akan merasa cemas dengan perubahan kondisi kesehatan bayinya. Kecemasan pada ibu membuat ibu merasa tidak nyaman, kurang optimal dalam melakukan perawatan pada bayi baru lahir seperti menyentuh, berinteraksi dengan bayi, tidak dapat menyusui bayi dengan leluasa dan produksi ASI sedikit (Gregson \& Blacker, 2011).

Kolcaba (1994) mendefinisikan kenyamanan sebagai suatu keadaan telah terpenuhi kebutuhan dasar manusia. Kebutuhan tersebut memiliki empat jenis yang berhubungan dengan pengalaman yang diterima BBLR, yaitu kebutuhan fisik, psikospiritual, sosiokultural dan lingkungan.

Model kenyamanan Kolcaba menjelaskan bahwa kenyamanan terbagi menjadi tiga tingkatan yaitu relief (keadaan yang membutuhkan penanganan kenyamanan), ease (keadaan BBLR yang dapat meregulasi stimulus) dan transendence (keadaan sejahtera BBLR). (Alligood \& Tomey, 2010).

BBLR $\begin{gathered}\text { Perawatan yang diberikan pada } \\ \text { bertujuan tercapainya }\end{gathered}$ kenyamanan sehingga diharapkan berat badan dapat meningkat dan dapat memfasilitasi perkembangan saraf BBLR (Ramachandran \& Dutta, 2013).

\section{Metode Penelitian}

Penelitian ini menggunakan desain studi kasus. Kasus yang diambil sebanyak 5. Tempat diadakan penelitian di ruang perawatan risiko tinggi neonatal (Perina) RSAB Harapan Kita dan RSUPN Cipto Mangunkusumo.

Penelitian dilakukan pada bulan Februari hingga April 2016. Sampel dalam penelitian adalah BBLR yang dirawat di Perina dengan gangguan pemenuhan kebutuhan nutrisi di antaranya kasus prematuritas murni, hiperbilirubinemia, atresia ani dan sepsis, gastoschizis dan atresia ileum, serta gangguan respirasi. Data didapatkan dari catatan medis, keperawatan dan 
observasi BBLR. Intervensi utama yang diterapkan adalah perawatan metode kanguru.

\section{Hasil Penelitian}

Kasus 1, Bayi O, laki-laki lahir tanggal 10 Januari 2016 dengan usia gestasi 29 minggu. Berat badan lahir 900 gram, lahir secara seksio sesaria. Diagnosis medis: Neonatus kurang bulan - sesuai masa kehamilan, riwayat hialyn membran diseases (HMD) dan hiperbilirubinemia. Residen keperawatan anak melakukan pengkajian tanggal 15 februari 2016 (usia 36 hari): Bayi O di dalam inkubator dengan suhu inkubator $31^{\circ} \mathrm{C}$, suhu tubuh $36,6^{\circ} \mathrm{C}$.

Kesadaran sadar penuh. Berat badan saat ini 1325 gram, terpasang orogastric tube (OGT), panjang badan saat ini $37 \mathrm{~cm}$, mendapatkan ASI 10 x 20 ml ditambah HMF $1 / 3$ bungkus setiap minum. Total kebutuhan cairan 150 $\mathrm{ml} / \mathrm{kgBB} / \mathrm{hari}$, toleransi minum baik, daya isap lemah.

Diagnosis keperawatan yang teridentifikasi yaitu risiko ketidakefektifan termoregulasi: Hipotermia, ketidakefektifan pola menyusu pada bayi, ketidakcukupan produksi ASI, kesiapan merawat bayi.

Implementasi yang dilakukan yaitu mengevaluasi tanda-tanda vital bayi, memberikan edukasi dan memfasilitasi perawatan metode kanguru melatih ibu memberikan minum melalui cawan, memutar musik selama perawatan metode kanguru, melakukan pijat bayi dan pijat oral, melibatkan orang tua dalam perawatan bayi, memberikan obat sesuai program, menganalisis hasil laboratorium.

Evaluasi asuhan keperawatan setelah 3 hari yaitu risiko ketidakefektifan termoregulasi: Hipotermia tidak terjadi, ketidakefektifan pola menyusu pada bayi teratasi, ketidakcukupan produksi ASI teratasi, kesiapan merawat bayi.

Kasus 2, Bayi Ny. YJ, laki-laki, lahir tanggal 4 Maret 2016 secara spontan, usia gestasi 31 minggu dan berat badan lahir 1677 gram. Diagnosis medis: Neonatus kurang bulan - kurang masa kehamilan, hialyn membran diseases (HMD), hiperbilirubinemia.

Hasil pemeriksaan fisik tanggal 7 maret 2016 (usia 3 hari) yaitu bayi di dalam inkubator dengan suhu $31^{\circ} \mathrm{C}$, suhu tubuh $37^{\circ} \mathrm{C}$, kesadaran sadar penuh, terpasang fototerapi. Terpasang alat bantu nafas continous positive airway pressure (CPAP) buble dengan $\mathrm{FiO} 2$ 25\%, PEEP 6. Terpasang orogastric tube (OGT), toleransi minum baik.

Terapi parenteral yang didapatkan yaitu $\mathrm{N}_{4} \mathrm{D} 10 \% \mathrm{~K}, \mathrm{Cl} 7,4 \%$, Ca glukonas dengan kecepatan tetesan $5 \mathrm{ml}$ per jam, asam amino $6 \%$ dengan kecepatan tetesan $3 \mathrm{ml}$ per jam. ASI/SF $4 \times 2,5 \mathrm{ml}$, $4 \times 5 \mathrm{ml}$. Berat badan saat ini 1497 gram, daya isap dan menelan lemah, total kebutuhan cairan $150 \mathrm{ml} / \mathrm{kgBB} / \mathrm{hr}$. Turgor kulit cukup, membran mukosa bibir lembab, berwarna merah muda, kulit nampak kering, waktu pengisian kapiler kurang dari 2 detik. Bayi mendapat terapi antibiotik. Golongan darah ayah $\mathrm{AB}$, ibu $\mathrm{B}+$ dan bayi $\mathrm{B}+$.

Diagnosis keperawatan yang teridentifikasi yaitu pola nafas tidak efektif, ketidakefektifan pola menyusu, risiko kekurangan volume cairan, risiko infeksi dan ketidakcukupan produksi ASI.

Implementasi yang diberikan: Mengevaluasi tanda-tanda vital, perawatan nasal pronge, mengganti posisi, memberikan minyak kelapa pada kulit yang kering, mengevalusi hasil lab, mengevaluasi pola nafas, memberikan edukasi dan memfasilitasi perawatan metode kanguru, memutar musik selama perawatan metode kanguru, memberikan pijat oral.

Evaluasi asuhan keperawatan setelah 3 hari yaitu pola nafas tidak efektif teratasi sebagian, ketidakefektifan pola menyusu teratasi sebagian, risiko kekurangan volume cairan tidak terjadi, risiko infeksi tidak terjadi dan ketidakcukupan produksi ASI teratasi 
Kasus 3, Bayi A, perempuan, lahir 7 Maret 2016 di RSAB Harapan Kita. Usia gestasi 39 minggu, berat badan lahir 1700 gram. Diagnosis medis: neonatus cukup bulan - sesuai masa kehamilan, pasca operasi atresia ani hari kelima dan tersangka sepsis.

Hasil pengkajan tanggal 15 maret 2016 (usia 8 hari) adalah: Bayi berada di dalam inkubator dengan suhu $31^{\circ} \mathrm{C}$, suhu tubuh $36,4^{\circ} \mathrm{C}$, berat badan saat ini 1653 gram, daya isap lemah, kebutuhan nutrisi/cairan terpenuhi dengan nutrisi enteral continue selama 1 jam.

Total parenteral nutrisi yang didapatkan adalah dekstrose 5\% dengan kecepatan tetesan $0,3 \mathrm{ml}$ per am, asam amino 6\% dengan kecepatan tetesan 4,1 $\mathrm{ml}$ per jam. Mendapatkan ASI/susu formula 4x12, 4x15 ml. Total kebutuhan cairan $130 \mathrm{ml} / \mathrm{kgBB} / \mathrm{hari}$, terdapat muntah susu cerna sebanyak $5 \mathrm{ml}$, abdomen teraba keras, lingkar perut 29 $\mathrm{cm}$ (lingkar perut lahir $26 \mathrm{~cm}$ ).

Konsistensi feses lembek, berwarna kuning melalui stoma. Nampak hematoma di area penusukan intravena. Frekuensi buang air kecil 4-5 kali per hari. Hasil pemeriksaan laboratorium pada tanggal 14 Maret 2016 yaitu hemoglobin 11,9 g/dl, hematokrit $36 \%$, leukosit 23,980 103/ $\mu 1$, trombosit 515,000 $10^{3} / \mu 1$, CRP $12,2 \mathrm{mg} / \mathrm{L}$, Natrium serum $138 \mathrm{mEq} / \mathrm{L}$, Kalium serum $6 \mathrm{mEq} / \mathrm{L}$, klorida serum $97 \mathrm{mEq} / \mathrm{L}$, penyebab sepsis adalah kuman acinobacter baumannii.

\begin{tabular}{lcc}
\multicolumn{1}{c}{ Diagnosis } & keperawatan yang \\
teridentifikasi & yaitu infeksi, \\
ketidakefektifan pola menyusu, risiko \\
ketidakefektifan
\end{tabular}

Hipotermia, risiko kekurangan volume cairan, ketidakcukupan produksi ASI, risiko gangguan perlekatan orangtua dan bayi.

Implementasi yang diberikan yaitu mengevaluasi tanda-tanda vital, merubah posisi, memberikan pijatan pada bayi, memutar musik selama pemberian minum, memberikan edukasi dan memfaslitasi perawatan metode kanguru, perawatan kolostomi, memandikan, mengganti popok, memfasilitasi perawatan metode kanguru, stimulasi oral.

Evaluasi asuhan keperawatan setelah 3 hari yaitu Infeksi teratasi sebagian, ketidakefektifan pola menyusu pada bayi teratasi sebagian, risiko ketidakefektifan termoregulasi: Hipotermia teratasi sebagian, risiko kekurangan volume cairan teratasi sebagian, ketidakcukupan produksi ASI teratasi, risiko gangguan perlekatan orangtua dan bayi tidak terjadi

Kasus 4, Bayi Ny. P, laki-laki, lahir 27 Januari 2016 di RSUPN Dr. Cipto Mangunkusumo secara seksio sesaria. Usia gestasi 35 minggu, berat badan lahir 2100 gram, panjang badan lahir $44 \mathrm{~cm}$.

Diagnosis medis: Neonatus kurang bulan - sesuai masa kehamilan, pasca operasi penutupan defek, reseksi ileum dan pembuatan ileustoma, memiliki riwayat hipoalbumin dan anemia. Pengkajian tanggal 28 maret 2016 (pasca operasi 1 bulan) yaitu kesadaran bayi sadar penuh, bayi berada di dalam inkubator dengan suhu $30,5^{\circ} \mathrm{C}$, suhu tubuh $36^{\circ} \mathrm{C}$. Berat badan saat ini 2310 gram, status nutrisi kurang.

Terapi parenteral nutrisi menggunakan $\mathrm{PG}_{2}$ dengan kecepatan 6 $\mathrm{ml}$ per jam dan $\mathrm{IL}_{20}$ dengan kecepatan 1 $\mathrm{ml}$ per jam. Diit pregistimil $8 \times 25 \mathrm{ml}$, total kebutuhan cairan $160 \mathrm{ml} / \mathrm{kgBB} / \mathrm{hr}$.

Turgor kulit cukup, membran mukosa bibir merah muda, waktu pengisian kapiler kurang dari 2 detik, tidak ada cekung mata, balans cairan per 24 jam adalah 55,5 $\mathrm{ml}$ per hari, diuresis cairan $2 \mathrm{ml} / \mathrm{kgBB} / \mathrm{jam}$, pengeluaran cairan melalui stoma adalah 77,04 $\mathrm{ml} / \mathrm{kgBB} / \mathrm{jam}$. Saat ini bayi mengalami high output ileustoma.

Hasil pemeriksaan laboratorium tanggal 27 maret 2016 adalah Hemoglobin 9,8 g/dl, Hematokrit 26,8\%,

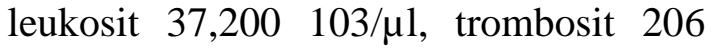

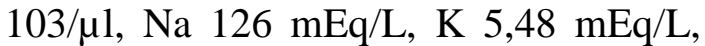


Cl $96 \mathrm{mEq} / \mathrm{L}$, IT rasio 0,2, CRP 38,3 $\mathrm{mg} / \mathrm{L}$.

\begin{tabular}{ccc}
$\quad$ Diagnosis & $\begin{array}{c}\text { keperawatan } \\
\text { yaitu }\end{array}$ \\
teridentifikasi & risiko \\
ketidakefektifan & \multicolumn{2}{c}{ termoregulasi: }
\end{tabular}

Hipotermia, kekurangan volume cairan, ketidakseimbangan nutrisi: Kurang dari kebutuhan tubuh, risiko infeksi, ketidakcukupan produksi ASI.

Implementasi yang diberikan adalah mengevaluasi tanda-tanda vital, memberikan edukasi dan memfasilitasi perawatan metode kanguru, memutar musik, memberikan makan melalui orogastric tube (OGT), perawatan ieustoma, mengganti posisi, menghitung balans cairan per 6 jam dan 24 jam, memberikan obat sesuai program, melibatkan orang tua dalam perawatan, mengganti posisi.

Evaluasi selama 3 hari yaitu risiko ketidakefektifan termoregulasi: Hipotermia tidak terjadi, kekurangan volume cairan teratasi sebagian, ketidakseimbangan nutrisi: Kurang dari kebutuhan tubuh teratasi sebagian, risiko infeksi tidak terjadi, ketidakcukupan produksi ASI teratasi.

Kasus 5, Bayi Ny. A, laki-laki, lahir di RSUPN Dr. Cipto mangunkusumo, tanggal 24 Maret 2016. Usia gestasi 33 minggu, berat badan lahir 1330 gram, panjang badan lahir $38 \mathrm{~cm}$. Diagnosis medis saat ini neonatus kurang bulan - sesuai masa kehamilan, riwayat respiratory distress (RD), penutupan patent ductus arterious (PDA).

Pengkajian tanggal 5 april 2016 (usia 11 hari) adalah berat badan saat ini 1300 gram. Terpasang alat bantu nafas high flow nasal (HFN) dengan $\mathrm{FiO} 2$ $21 \%$, flow trigger 2, saturasi oksigen saat ini $88 \%$. Suhu inkubator $32^{\circ} \mathrm{C}$, suhu tubuh $35,8^{\circ} \mathrm{C}$. Kesadaran sadar penuh. Diit ASI $8 \times 25 \mathrm{ml}$ melalui enteral kontinue selama 1 jam, total kebutuhan cairan $150 \mathrm{ml} / \mathrm{kgBB} /$ hari. toleransi minum baik, terdapat muntah $2 x$.

Diagnosis keperawatan yang teridentifikasi yaitu risiko ketidakefektifan termoregulasi:
Hipotermia, pola nafas tidak efektif, ketidakefektifan pola menyusu pada bayi, risiko ketidakcukupan produksi ASI.

Implementasi yang diberikan adalah mengevaluasi tanda-tanda vital, memantau status pernafasan, memberikan edukasi dan memfasilitasi perawatan metode kanguru, memutar musik selama perawatan metode kanguru, mengganti posisi, memantau ketidaknyamanan, memberikan nutrisi atau cairan melalui orogastric tube (OGT) atau melaui cawan.

Evaluasi asuhan keperawatan setelah 3 hari yaitu risiko ketidakefektifan termoregulasi: Hipotermia tidak terjadi, pola nafas tidak efektif teratasi sebagian, ketidakefektifan pola menyusu pada bayi teratasi, risiko ketidakcukupan produksi ASI teratasi.

\section{Pembahasan}

Hasil pengkajian status nutrisi pada kelima kasus terpilih menunjukkan sebagian besar mengalami masalah kenyamanan fisik jenis relief pada status nutrisi, dimanifestasikan dengan gambaran grafik Fenton.

Status nutrisi pada kasus satu sampai dengan lima adalah dibawah persentil $50 \%$ dan para orang tua bayi memiliki keluhan sama yaitu produksi ASI tidak banyak.

Orang tua BBLR pada kasus empat diberhentikan sementara pemberian ASI dengan pertimbangan pada kasus bedah protein yang diberikan harus dalam jumlah kecil agar dapat diserap tubuh dengan baik.

Kondisi klinis bayi mempengaruhi kecemasan pada ibu. Menurut Morey dan Gregory (2012), ibu yang memiliki BBLR, usia gestasi rendah dan bayi dengan resiko tinggi lebih banyak menghabiskan waktu di NICU dan menunjukkan kecemasan yang tinggi.

Ibu yang mengalami kecemasan juga akan mempengaruhi produksi ASI, sehingga kebutuhan nutrisi bayi tidak sepenuhnya didapatkan dari ibu, namun 
perlu dibantu dengan nutrisi tambahan yaitu melalui nutrisi parenteral (Dewey, 2006).

Pada kelima kasus terpilih, empat diantaranya merupakan bayi dengan usia gestasi kurang dari 38 minggu. Status nutrisi bayi juga dipengaruhi oleh usia gestasi. Menurut Marofi, Abedini, Mohammadizadeh dan Talakoub (2016), usia gestasi mempengaruhi peningkatan berat badan.

Bayi dengan usia gestasi yang lebih tinggi mempunyai berat badan yang lebih besar. Berat badan bayi berhubungan dengan nutrisi dan suhu tubuh. Nutrisi yang optimal merupakan upaya yang penting dalam peningkatan berat badan bayi. BBLR mempunyai fungsi pencernaan yang masih terbatas.

Diagnosis keperawatan utama yang muncul adalah ketidakefektifan pola menyusu pada bayi, ketidakseimbangan nutrisi: Kurang dari kebutuhan tubuh, ketdakcukupan produksi ASI. Merujuk Herdman dan Kamitsuru (2015) pada buku diagnosis keperawatan 2015-2017 meyebutkan masalah keperawatan yang termasuk domain nutrisi terdapat 21 diagnosis keperawatan.

Pada kelima kasus yang dibahas, diagnosis keperawatan untuk status nutrisi sebanyak 5. Selain mengangkat diagnosis keperawatan status nutrisi, terdapat juga diagnosis ketidakefektifan pola nafas, risiko infeksi, ketidakefektifan termoregulasi: Hipotermia.

Intervensi utama menggunakan perawatan metode kanguru. Perawatan metode kanguru (PMK) dipilih menjadi intervensi utama karena BBLR dan orang tua tidak dapat dipisahkan begitu saja. Bayi yang mengalami hospitalisasi akan mengalami perpisahan sementara dengan orang tuanya dan akan mengakibatkan berbagai macam hal, diantaranya lama rawat meningkat, proses penyembuhan bayi menjadi lama dan bayi kurang mendapatkan kasih sayang (Cockroft, 2012).
Pada kasus terpilih satu bayi $\mathrm{O}$ mengalami peningkatan berat badan 2030 gram per hari. Hal ini dikarenakan selain pemberian perawatan metode kanguru, bayi $\mathrm{O}$ juga mendapatkan human milk fortifier sebagai suplemen tambahan nutrisi bayi.

Underwood (2013) dan Su (2014) menyampaikan bahwa human milk fortifier dapat digunakan sebagai suplemen tambahan apabila produksi ASI tidak mencukupi harian bayi. Kandungan human milk fortifier yaitu laktosa, merupakan sumber utama energi yang dibutuhkan untuk aktivitas, oligosakarida kompleks, molekul bioaktif dan yang diperlukan untuk peningkatan berat badan bayi.

Pada kasus terpilih tiga, bayi dengan sepsis, mengalami peningkatan berat badan tidak seperti kasus terpilih lainnya, yaitu 10-15 gram per hari, sementara bayi pada kasus 1,2,4,5 mengalami peningkatan berat badan 2030 gram per hari.

Hal ini dapat disebabkan beratnya penyakit yang di derita oleh bayi. Keadaan penyakit infeksi sampai dengan sepsis mengakibatkan ketidakseimbangan tubuh, hal ini nampak dari terdapatnya ketidakefektifan termoregulasi yang mengakibatkan asupan energi lebih banyak akibat pengeluaran energi yang banyak pula sehingga, energi yang seharusnya digunakan untuk pertumbuhan digunakan untuk mengembalikan kenyamanan BBLR.

Pada kasus empat yang mengalami high output stoma, bayi diberikan total parenteral nutrition (TPN), namun nutrisi parenteral yang diberikan termasuk jenis nutrisi parenteral parsial. Hanya sebagian nutrien diberikan melalui nutrisi parenteral, sedangkan lainnya diberikan melalui oral.

Villafranca et al (2015) menemukan high output stoma terjadi pada $16 \%$ kasus ileostomi dan jejunostomi. Selain itu ditemukan juga pasien yang memiliki sisa usus kecil 
proksimal kurang dari $200 \mathrm{~cm}$ dan infeksi intra abdominal sebagai penyebab paling umum terjadinya high output stoma. Mohil, Narayan, Sreenivas, Singh, Bansal dan Singh (2015) menjelaskan bahwa salah satu akibat dari terjadinya high output stoma adalah terjadi malnutrisi karena malabsorbsi dengan kadar albumin yang rendah.

Pada kelima kasus terpilih, tiga diantaranya mendapatkan nutrisi secara enteral. Lestari (2011) menjelaskan bahwa pasien yang mendapatkan nutrisi enteral adalah pasien yang tidak mampu mendapatkan kecukupan kalori secara oral tetapi fungsi ususnya masih normal.

Pasien yang membutuhkan nutrisi enteral antara lain pasien yang berat badannya tidak meningkat secara memadai, pertumbuhan tidak adekuat, anak yang membutuhkan waktu makan yang lama, anak yang kehilangan berat badan secara terus menerus, anak yang mengalami penurunan rasio berat/umur atau berat/ tinggi badan atau anak dengan masalah pada oral atau lambung

PMK pada kelima kasus menunjukkan perubahan status kenyamanan bayi. Hal ini nampak pada status fisiologi, frekuensi pernafasan, nadi, status respirasi yang membaik dan suhu tubuh yang membaik.

Penelitian yang dilakukan oleh Moore, Anderson, Bergman, dan Dowswell (2012) mengenai pengaruh skin to skin contact melalui PMK terhadap adaptasi fisiologis dan adaptasi perilaku ibu-bayi. Hasil penelitian menyebutkan bahwa skin to skin contact secara signifikan berpengaruh pada proses menyusu bayi, sabilitas kardiorespirasi dan menurunkan menangis bayi.

Peningkatan berat badan disebabkan oleh meningkatnya hubungan bayi dan ibu, dimana bayi mempunyai waktu yang lebih lama untuk menyusu.

Hal ini sesuai dengan Chan, Labar, Wall dan Atuna (2016) yang menyatakan bahwa PMK meningkatkan bonding ibu-bayi, meningkatkan pengeluaran hormon oksitosin, menjaga kestabilan kenyamanan bayi selama masa transisi intrauterine ke ekstrauterin.

Evaluasi penerapan model kenyamanan Kolcaba untuk mengatasi masalah nutrisi pada BBLR melalui intervensi perawatan metode kanguru dapat dikatakan berhasil ditandai dengan adanya peningkatan berat badan BBLR perhari, hipotermia teratasi, produksi ASI meningkat.

\section{Kesimpulan}

Model kenyamanan Kolcaba merupakan teori keperawatan tingkat middle range sehingga model kenyamanan ini dapat dengan mudah diterapkan di tatanan klinis.

Model kenyamanan Kolcaba dapat diterapkan pula untuk mengatasi berbagai kasus penyakit. Yang dibutuhkan adalah kecakapan perawat untuk mengkaji, mengelompokkan masalah yang ada dan melihat respon BBLR setelah melakukan implementasi.

\section{Ucapan Terima Kasih}

Pihak RSUPN Dr. Cipto Mangunkusumo dan RSAB Harapan Kita khususnya para dokter, kepala ruang dan staf perawat di ruang perinatologi dan NICU yang telah memberikan banyak bantuan selama residen keperawatan anak praktik.

\section{Daftar Pustaka}

[1] Aritonanga, E., Rajagukguk, T., \& Nasution, E. (2015). Analysis of body weight in low birth weight infant based on breastfeeding and formula milk for two weeks nursing in santa elisabeth hospital medan. IJSBAR, 23 (1), 308-317. ISSN 2307-4531.

[2] Alligood, M. A., \& Tomey, A. M. (2010). Nursing theorists and their work (7th ed). St. Louis: Mosby Elsevier.

[3] Altimier, L. (2011). Mother and child integrative developmental care model: A simple approach to a complex population. Newborn \& 
Infant Nursing Reviews, 11 (3), 105108.

[4] Altimier, L., \& Phillips, R. M. (2013). The neonatal integrative developmental care model: Seven neuroprotective core measures for family-centered developmental care. Newborn \& Infant Nursing Reviews, 13(2013), 9-22.

[5] Beiranvand, S., Valizadeh, F., Hosseinabadi, R., \& Pournia, Y. (2014). The effects of skin-to-skin contact on temperature and breastfeeding sumlessfulness in fullterm newborns after cesarean delivery. International Journal of Pediatrics, 2014, 1-7.

[6] Benzies1, K.M., Magill-Evans, J.E., Hayden, K.A., \& Ballantyne, M. (2013). Key components of early intervention programs for preterm infants and their parents: A systematic review and metaanalysis. BMC Pregnancy and Childbirth Journal, 13 (1), 1-15.

[7] Chan, G.J., Labar, A.S., Wall, S., \& Atuna, R. (2016). Kangaroo mother care: A systematic review of barriers and enablers. Bull World Health Organ, 94, 130-141. Doi: http://dx.doi.org/10.2471/BLT.15.15 7818.

[8] Cockroft, S. (2012). How can family centered care be improved to meet the needs of parents with a premature baby in Neonatal intensive care?. Journal of Neonatal Nursing, 18, 105-110.

[9] Dewey, K.G. (2006). Maternal and fetal stress are associated with impaired lactogenesis in humans. American Society for Nutritional Science, 131, 3012-3015.

[10] Gregson, S., \& Blacker, J. (2011). Kangaroo care in preterm or low birth weight babies in a postnatal ward. British Journal of Midwifery, 19 (9), 566-575.

[11] Herdman, T.H., \& Kamitsuru, S. (2014). NANDA international nursing diagnoses: Definitions \& classification 2015-2017 (10th ed). Oxford: Wiley Blackwell.

[12] Kolcaba, K., (1994). A Theory of holistic comfort for nursing. Journal of Advance Nursing, 19, 1178-1184.

[13] Kolcaba, K., \& DiMarco, M. (2005). Comfort theory and its application to pediatric nursing. Pediatric Nursing, 31(3), 187-194.

[14]Lestari, E.D. (2011). Buku ajar nutrisi pediatrik dan penyakit metabolik: Nutrisi enteral. Jakarta: IDAI.

[15] Marofi, M., Abedini, F., Mohammadizadeh, M., \& Talakoub, S. (2016). Effect of palady and cup feeding on premature neonates' weight gain and reaching full oral feeding time interval. Iranian Journal of Nursing and Midwifery Research, 21 (2), 202-206. Doi: 10.4103/1735-9066.178249.

[16] Mohil, R.S., Narayan, N., Sreenivas, S., Singh, N., Bansal, A., \& Singh, G.J. (2015). Challenges of managing emergency ileostomy: Nutrition - A neglected aspect. International Scholarly Research Network, 12, 16. Doi:10.5402/2012/968023

[17] Moore, E.R., Anderson, G.C., Bergman, N., \& Dowswell, T. (2012). Early skin-to-skin contact for mothers and their healthy newborn infants. Cochrane Database Syst Rev, 5, 1-75.

[18] Su, B. (2014). Optimizing nutrition in preterm infants. Pediatrics \& Neonatology Journal, 55 (1), 5-13.

[19] Udani, R.H., Hinduja, A.R., Rao, S., \& Kabra, N.S. (2014). Role of kangaroo mother care in preventing neonatal morbidity in the hospital and community: A review article. Journal of Neonatology, 28 (4), 2936.

[20] Underwood, M.A. (2012). Human milk for the premature infant. Pediatr Clin North Am, 60 (1), 189 207. Doi: 10.1016/j.pcl.2012.09.008.

[21] Villafranca, J.A., López-Rodríguez, C., Abilés, J., Rivera, R., Adán, 
N.G., 4., \& Navarro, P.U. (2015).

Protocol for the detection and nutritional management of highoutput stomas. Nutrition Journal, 14 (45), 1-7. Doi: 10.1186/s12937-0150034-z. 